\section{Ethyl chloride and venepuncture pain: a comparison with intradermal lidocaine}

P. Armstrong BSc FCAnaes, C. Young FCAnaes, D. McKeown FCAnaes

\begin{abstract}
One hundred and twenty unpremedicated patients undergoing gynaecological surgery were randomly allocated to one of three equal treatment groups to assess the effectiveness of ethyl chloride in producing instant skin anaesthesia to prevent the pain of venepuncture from a $20 \mathrm{G}$ cannula. They received either no anaesthetic, $0.2 \mathrm{ml}$ one per cent lidocaine plain intradermally or a ten-second spray of ethyl chloride at the cannulation site. Ethyl chloride produced skin anaesthesia that significantly reduced the pain of venepuncture. However, it was not as effective as intradermal lidocaine. It had no effect on vein visualisation or ease of cannulation. Ethyl chloride can be recommended as a method of producing instant skin anaesthesia.
\end{abstract}

Afin d'évaluer l'anesthésie cutanée produite par le chlorure d'éthyl, nous avons randomisé en trois groupes, 120 candidates d une chirurgie gynécologique n'ayant pas reçu de prémédication. Avant l'insertion percutanée d' une canule de calibre 20. nous n'utilisions soit aucun agent, soit une injection intradermique de $0,2 \mathrm{ml}$ de lidocaïne une pour cent, soit une vaporisation de chlorure d'éthyl de dix secondes au site d'insertion. Le chlorure d'éthyl produit alors une anesthésie cutanée capable de diminuer la douleur lors de l'insertion d' une canule veineuse (mais pas de façon aussi marquée que la lidocaïne) sans en compliquer la technique ni entraver la visualisation de la veine. Il s'agit donc là d'une technique acceptable d'anesthésie culanée presque instantanée.

Venous access for induction of anaesthesia often causes pain and anxiety to patients. Painfree venepuncture can be obtained by the use of eutectic mixture of local anaesthetic. This method, however, requires a minimum of $60 \mathrm{~min}$ application time under an occlusive dressing. ' A percuta-

\section{Key words}

ANAESTHETIC TECHNIQUES: skin; ANAESTHETICS, LOCAL: ethyl chloride, lidocaine.

From the Department of Anaesthesia, Royal Infirmary of Edinburgh, Lauriston Place, Edinburgh EH3 9YW, Scotland. neous amethocaine preparation gave a faster onset of anaesthesia but still required an onset time of $30 \mathrm{~min}^{2}$ This prolonged onset of action often results in patients arriving for induction with inadequate skin anaesthesia.

Instantaneous skin anaesthesia can be achieved using an intradermal injection of local anaesthetic although this in itself may be painful due either to penetration of the skin by the needle or to tissue distortion by the injected local anaesthetic. Another method involves the use of ethyl chloride spray; its cooling effect freezes and so anaesthetizes the skin. However, we have been unable to find studies to support this practice or to compare it with other methods of skin anaesthesia.

This study was designed to investigate the effectiveness of ethyl chloride in providing instantaneous skin anaesthesia to reduce the pain of venepuncture and to compare its efficacy with that obtained with intradermal lidocaine.

\section{Methods}

One hundred and twenty unpremedicated female patients undergoing minor gynaecological day-case surgery acted as the subjects in the study which had received approval from the local ethics committee. Informed consent was obtained and the patients allocated to one of three equal-sized treatment groups using a table of random numbers. Group I received no treatment prior to cannulation. Group 2 received $0.2 \mathrm{ml}$ lidocaine plain injected intradermally through a $25 \mathrm{G}$ needle at the puncture site of the skin and Group 3 had ethyl chloride sprayed around the skin's puncture site from a height of eight inches for ten seconds. A suitable vein on the dorsum of the left hand was then cannulated with a $20 \mathrm{G}$ cannula $30 \mathrm{sec}$ after the lidocaine injection and immediately after the ethyl chloride spray.

All cannulations and assessments were made by the same anaesthetist (CY). Technical difficulties of cannulation which were assessed by the investigator included vein visibility before and after skin anaesthesia and ease of cannula insertion using a five-point scale $(0=$ difficult, 4 = easy). The patients assessed the pain of the anaesthetic application, of catheter insertion, and the skin pain one minute after insertion using a $10-\mathrm{cm}$ visual 
TABLE I Vein visibility and ease of cannulation (mean $\pm S D$ )

\begin{tabular}{llll}
\hline & $\begin{array}{l}\text { Group I } \\
\text { Nil }\end{array}$ & $\begin{array}{l}\text { Group 2 } \\
\text { Lidocaine }\end{array}$ & $\begin{array}{l}\text { Group 3 } \\
\text { Ethyl chloride }\end{array}$ \\
\hline $\begin{array}{l}\text { Vein visibility prior to } \\
\text { anaesthetic }\end{array}$ & $2.7 \pm 1.2$ & $2.9 \pm 1.2$ & $2.9 \pm 1.3$ \\
$\begin{array}{l}\text { Vein visibility after } \\
\text { anaesthetic }\end{array}$ & $2.7 \pm 1.2$ & $1.9 \pm 1.4$ & $2.8 \pm 1.4$ \\
Ease of cannulation & $3.4 \pm 1.1$ & $2.8 \pm 1.2^{*}$ & $3.3 \pm 1.0$ \\
\hline
\end{tabular}

$* P<0.05$ vs groups 1 and 3 (Mann-Whitney U Test)

analogue score with a range of no pain (left edge) to the severest pain imaginable (right edge).

Statistical analysis for patient demographic data was performed using analysis of variance (ANOVA). For technical cannulation difficulties and VAS pain scores the Kruschal-Wallis (K-W) non-parametric analysis of variance test was used with the Mann Whitney test and application of the Bonferroni correction for comparison among groups.

\section{Results}

There were no statistical differences among the three groups in respect of age and weight (ANOVA). All groups had similar visibility of their veins initially (Table I). Following application of the local anaesthetic, there was a difference in venous visibility between the groups $(P<0.01, \mathrm{~K}-\mathrm{W})$; the ethyl chloride spray having no effect whilst the intradermal lidocaine impaired it (Table I). Ethyl chloride had no effect on the ease of insertion of the cannula whilst intradermal lidocaine increased the cannulation difficulty compared with both the control and the ethyl chloride spray groups $(P<0.05, \mathrm{~K}-\mathrm{W})$.

There was no difference in the pain of application between ethyl chloride spray and intradermal lidocaine (Table II). Lidocaine was superior in reducing the pain of catheter insertion compared with either the control or the ethyl chloride spray groups $(P<0.01, \mathrm{~K}-\mathrm{W})$. Ethyl chloride spray reduced the pain of catheter insertion compared with the control group. There was also a difference in pain after one minute among these groups ( $P$ $<0.0001$ ) with the lidocaine group reducing the pain in comparison with the other two. The ethyl chloride spray group produced no decrease in pain.

The skin was blanched after ethyl chloride spray in every subject but remained blanched in only five after 30 sec.

\section{Discussion}

Topical local anaesthetics, whilst producing good skin anaesthesia, have disadvantages. Time is required to produce anaesthesia which often results in incomplete anaesthesia. ${ }^{1,2}$ Plasma concentrations of the local anaes-
TABLE II Visual analogue scores for pain (mean \pm SD)

\begin{tabular}{llll}
\hline & $\begin{array}{l}\text { Group 1 } \\
\text { Nil }\end{array}$ & $\begin{array}{l}\text { Group 2 } \\
\text { Lignocaine }\end{array}$ & $\begin{array}{l}\text { Group 2 } \\
\text { Elhylchloride }\end{array}$ \\
\hline Application of anaesthetic & - & $2.5 \pm 1.6$ & $1.8 \pm 1.5$ \\
Catheter insertion & $3.8 \pm 2.1$ & $0.7 \pm 0.9 *$ & $1.8 \pm 2.1 \neq$ \\
One minute after insertion & $2.9 \pm 2.4$ & $0.8 \pm 1.3 \dagger$ & $2.1 \pm 2.1$ \\
\hline
\end{tabular}

Mann-Whitney $U$ lest for significance of Groups 2 and 3 ( $^{*} P<0.01$, $\dagger P<0.001$ ). Comparison of Group I against group 2 all have a $P$ | 0.001 . Group 1 against Group 3 shows $\ddagger P<0.001$.

thetic can be raised considerably in children ${ }^{3}$ and there is often skin blanching or erythema. ${ }^{4}$ In addition, application of the cream restricts venepuncture to a single site on the skin and is expensive in both cost and nursing time. Refrigeration anaesthesia avoids these complications.

Ethyl chloride is a highly volatile anaesthetic readily obtainable in 50 - or $100-\mathrm{ml}$ glass tubes with a nozzle for spraying. On contact with the skin it vaporises and cools the surrounding area to $-20^{\circ} \mathrm{C}^{5}$ thereby freezing any water vapour present. This crystallises as a white precipitate. Its use in the relief of certain chronic painful conditions is well documented. ${ }^{6}$ It is also used in minor operative procedures although often the anaesthesia is patchy and, as the skin thaws out, intense pain may occur. ${ }^{7}$ None of the patients experienced this painful thawing perhaps because of the short duration of the spray.

Compared with intradermal lidocaine, ethyl chloride is less potent in producing skin anaesthesia, although it still has appreciable effects. It causes less interference with cannulation than lidocaine; even though it freezes the skin, no venoconstriction occurs and, unlike lidocaine, no tissue distortion occurs. The only contraindication to its use is in the rare condition of cold hypersensitivity. ${ }^{8}$

Ethyl chloride, when sprayed on the skin, provides instantaneous anaesthesia thereby reducing the pain of venepuncture though it was not as effective as intradermal lidocaine. Unfortunately, blinding of this study was impossible. Patients received obviously different treatments and observer assessment entailed skin examination. No treatment, the spray, and lidocaine all produced obvious differences to the skin. Some of the effects of ethyl chloride spray may thus be attributable to placebo or to observer and patient bias. However, it acts instantaneously and has no effect on cannulation difficulties unlike intradermal lidocaine. Its use in reducing the pain of venepuncture is recommended.

\section{Acknowledgement}

Dr. P. Armstrong is in receipt of a grant from the Association of Anaesthetists of Great Britain and Ireland. 


\section{References}

1 Ehrenstrom-Reiz G, Reiz S, Stockman O. Topical anaesthesia with EMLA, a new Lidocaine-Prilocaine cream and the Cusum technique for the detection of minimal application time. Acta Anaesthesiol Scand 1983; 27: 510-2.

2 McCafferty $D F$, Woolfson $A D$, Boston $V$. In vivo assessment of percutaneous local anaesthetic preparations. $\mathrm{Br}$ J Anaesth 1989; 62: 17-21.

3 Enberg $G$, Danielson $K$, Henneberg S, Nilsson A. Plasma concentrations of prilocaine and lidocaine and methaemoglobin formation in infants after epicutaneous application of a 5\% lidocaine-prilocaine cream (EMLA). Acta Anaesthesiol Scand 1987; 31: 624-8.

4 Editorial II. Anaesthesia of the skin. Br J Anaesth 1989; 62: 4-5.

5 Coleman AJ. Inhalational anaesthetic agents. In: ChurchillDavidson HC (Ed.). A Practice of Anaesthesia, 5th ed., London: Lloyd-Luke Ltd., 1984.

6 Bierman W. Therapeutic uses of cold. JAMA 1955; 157: 1189-92.

7 Sparks JP. Ethyl chloride as a local anaesthetic agent. Lancet 1968; 2: 1394.

8 Juhlin L, Shelley WB. Role of mast cells and basophils in cold urticaria with associated symtomatic reactions.

JAMA 1961; 117: 371-7. 